\title{
Antioxidant Activity of Endophytic Fungi Isolated from Turmeric Flowers
}

\author{
Eris Septiana $^{1}$, Yadi Yadi $^{1}$, Partomuan Simanjuntak ${ }^{1,2}$ \\ ${ }^{1}$ Laboratory of Natural Product Chemistry, Research Center for Biotechnology, Lembaga Ilmu Pengetahuan Indonesia \\ ${ }^{2}$ Faculty of Pharmacy, Universitas Pancasila, Indonesia. \\ *Email: septiana.eris@gmail.com
}

Submitted: 10 May 2020. Revised: 23 June 2020. Accepted: 7 July 2020

\begin{abstract}
Antioxidants are compounds needed by the body to fight free radicals that can cause adverse effects on health. All parts of turmeric plant have antioxidant activity, so does the flower. It is thought that the endophytic fungi from turmeric flowers also have antioxidant activity and no studies have reported it yet. The purpose of this study was to study the antioxidant activity of single and mixed cultures of endophytic fungi isolated from turmeric flowers. In vitro antioxidant activity assay was conducted using the DDPH (2,2-diphenyl-1-picrylhydrazyl) free radical scavenging method by measuring its absorption using a UV-Vis spectrophotometer at a wavelength of $517 \mathrm{~nm}$. The extract of single and mixed cultures of endophytic fungi isolated from turmeric flowers showed antioxidant activity. The combination of fungal cultures can increase the antioxidant activity of a single culture. This study is the first to report that the combination of endophytic fungi from turmeric flowers can increase its antioxidant activity. Therefore, the presence of the endophytic fungi in turmeric flowers that have antioxidant activity can provide additional information so that the utilization of turmeric flowers as a source of natural antioxidants will increase.
\end{abstract}

Key words: Antioxidant; Endophytic Fungi; Mixed Culture; Synergistic; Turmeric Flowers

How to Cite: Septiana, E., Yadi, Y., \& Simanjuntak, P. (2020). Antioxidant Activity of Endophytic Fungi Isolated from Turmeric Flowers. Biosaintifika: Journal of Biology \& Biology Education, 12 (2), 268-273

DOI: http://dx.doi.org/10.15294/biosaintifika.v12i2.24396

\section{INTRODUCTION}

Air pollution is a very important problem especially in cities with high level of mobility. Air pollution comes from various human activities such as cigarette smoke, vehicle exhaust as well as the results of industrial activities. This situation will greatly affect public health because it will increase the free radicals in the body. Increased free radicals in the body will cause a decrease in human immunity and increase the severity of several diseases due to oxidative stress experienced by the cells (Sitorus et al., 2017). The human body will naturally neutralize free radicals within normal limits through the immune system. The body will produce compounds to neutralize the free radicals called antioxidants. The presence of antioxidants is very important in order to protect the body from several diseases caused by free radicals formed (Khani et al., 2017).

The use of synthetic antioxidants has been reported to have several disadvantages. In addition to its low solubility in water, its use has also been banned because of its toxic and carcinogenic effects (Gulcin, 2012). Therefore, the use of natural antioxidants is increasing. One source of natural antioxidants is derived from plants. Medicinal plants are considered relatively safer for consumption because of their lack or even absence of side effects when compared to synthetic antioxidant (Priska et al.,
2019). Turmeric is one of the plants known to have a high natural antioxidant content (Tanvir et al., 2017). The content of antioxidants is mainly in the rhizome. However, besides rhizomes, flowers from turmeric plants also contain high antioxidants (Kumar et al., 2016).

Traditionally, turmeric is used directly as a source of antioxidant compounds. However, the use of endophytic microbes in turmeric plant tissue as a source of antioxidant compounds has also been widely carried out. Endophytic fungi are one of the endophytic microbes that live in the tissues of their host plants without causing symptoms of a disease, living in symbiotic mutualism with their hosts by producing secondary metabolites (Nicoletti \& Fiorentino, 2015). Previous studies reported that endophytic fungi from rhizomes and leaves of turmeric have antioxidant activity (Septiana et al., 2019a; Septiana et al., 2019b). However, there are no studies that report the endophytic fungi from turmeric flowers to have antioxidant activity. Therefore, this study aimed to determine the antioxidant activity of the extract of endophytic fungi isolated from turmeric flowers in the form of a single and mixed cultures. This research was expected to be able to enrich scientific information about the potential of endophytic fungi from turmeric that has never been studied before. It is hoped that the community can take more benefit from all parts of turmeric as a 
traditional medicine, especially as source of natural antioxidants.

\section{METHODS}

\section{Endophytic fungal isolates}

Endophytic fungal isolates used were collections of Natural Product Chemistry Laboratory, Research Center for Biotechnology, LIPI. Endophytic fungal isolates used were $\mathrm{Cl} . \mathrm{Bn} 1, \mathrm{Cl} . \mathrm{Bn} 2$, and $\mathrm{Cl} . \mathrm{Bn} 3$ (Figure 1) which were isolated from turmeric flower from Bogor, West Java.

\section{Fermentation and extraction of endophytic fungi}

Every single colony of endophytic fungi was rejuvenated by growing it on Potato Dextrose Agar (PDA) media, incubated at $30{ }^{\circ} \mathrm{C}$ for 7 days. After an incubation period, a few hyphae of endophytic fungal isolates were taken to be grown in $100 \mathrm{~mL}$ liquid fermentation media of Potato Dextrose Broth in seven $250 \mathrm{~mL}$ Erlenmeyer flasks. Every Erlenmeyer contained single culture of Cl.Bn1, Cl.Bn2, and Cl.Bn3, and mixed culture of Cl.Bn1-Cl.Bn2, Cl.Bn1Cl.Bn3, Cl.Bn2-Cl.Bn3, and Cl.Bn1-ClBn2-ClBn3. Fermentation was carried out on an incubator shaker with an agitation speed of $120 \mathrm{rpm}$ for 14 days at room temperature. After 14 days of fermentation, biomass and filtrate were separated. The biomass was dried in an oven at $60{ }^{\circ} \mathrm{C}$ for 24 hours and weighed. The filtrate was extracted using ethyl acetate and concentrated using a rotary vacuum evaporator and then weighed (Salini et al., 2015).

\section{Antioxidant activity test}

The antioxidant activity test was carried out by the DPPH free radicals scavenging method (Tiwari et al., 2006) with modifications at wavelength at $517 \mathrm{~nm}$. The concentrations of the sample solution used were 5, 10, 25, 50, and $100 \mu \mathrm{g} / \mathrm{ml}$; ascorbic acid (vitamin C) as a positive control of $1,3,5,7$ and $9 \mu \mathrm{g} / \mathrm{ml}$; and $0.04 \mathrm{mM}$ DPPH as blank. All sample solutions were incubated at $37{ }^{\circ} \mathrm{C}$ for 30 minutes. The absorption of the all samples was then measured at a wavelength of $517 \mathrm{~nm}$. $\mathrm{IC}_{50}$ value denotes the concentration of sample, which is required to scavenge $50 \%$ of DPPH free radicals. Radical scavenging activity was calculated by the following formula,

$\%$ inhibition $=(\mathrm{A}-\mathrm{B}) / \mathrm{A} \times 100 \%(1)$

Note: $\mathrm{A}=$ blank absorbance; $\mathrm{B}=$ absorbance of test material

$\mathrm{IC}_{50}$ value was determined from the plotted graph of scavenging activity against the different concentrations of extracts, which is defined as the total antioxidant necessary to decrease the initial DPPH radical concentration by $50 \%$.

\section{RESULTS AND DISCUSSION}

\section{Fermentation and extraction of endophytic fungi}

Endophytic fungal fermentation was done by using a shaker incubator with the aim to maintain the aeration and agitation properly. This is important because aeration is needed to supply oxygen to endophytic fungi, while agitation aims to increase oxygen supply in the media and maintain temperature uniformity (Kumala \& Pratiwi, 2014). In the fermentation results, there was no relationship between type of culture (single or mixed culture) and the weight of biomass and extracts produced (Table $1)$. The weight of biomass or extract is not directly proportional to the number of isolates combined. Nevertheless, the biomass of mixed culture of three endophytic fungi showed the highest value among single cultures and other combinations (Table 1). In this study, the extract used was only from the fermentation media because endophytic fungi will secrete secondary metabolites into growth media (Bustanussalam et al., 2015). It was expected that the extract obtained contains secondary metabolites with antioxidant activity.
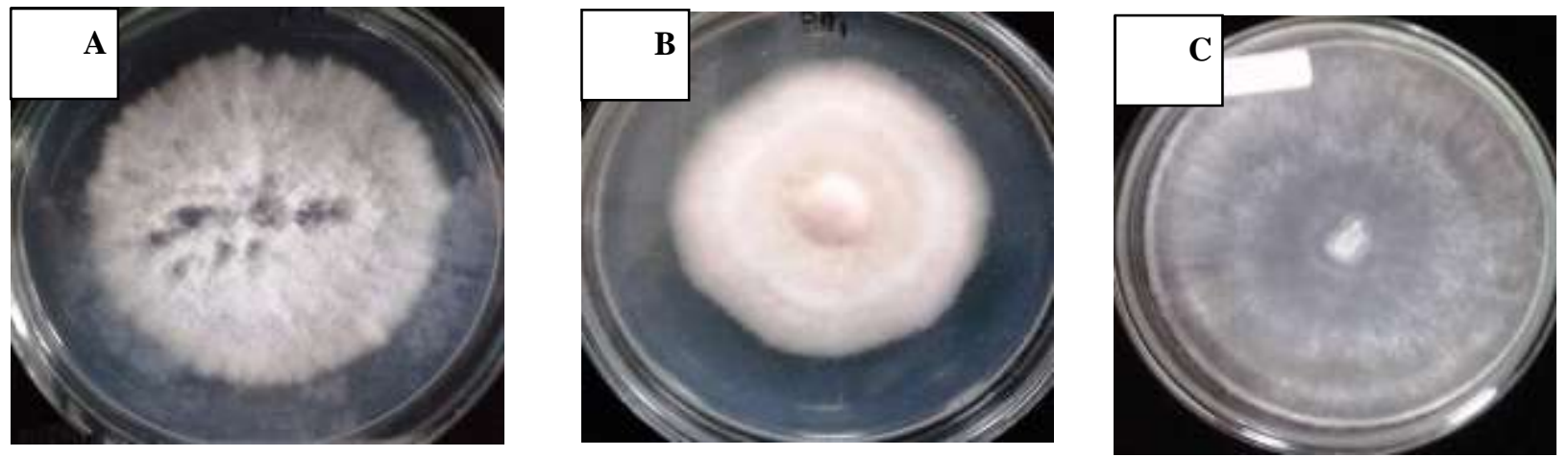

Figure 1. The endophytic fungi obtain from turmeric flowers with code Cl.Bn1 (A), Cl.Bn2 (B), and Cl.Bn3 (C). 
Table 1. Biomass and extraction yield of endophytic fungi isolated from turmeric flowers

\begin{tabular}{lll}
\hline Isolates & Biomass $(\mathrm{g})$ & Extract $(\mathrm{g})$ \\
\hline Cl.Bn1 & 0.4243 & 0.0169 \\
Cl.Bn2 & 0.5442 & 0.0134 \\
Cl.Bn3 & 0.3993 & 0.0141 \\
Cl.Bn1+2 & 0.2205 & 0.0215 \\
Cl.Bn1+3 & 0.4193 & 0.0156 \\
Cl.Bn2+3 & 0.2694 & 0.0299 \\
Cl.Bn1+2+3 & 0.5452 & 0.0181 \\
\hline
\end{tabular}

\section{Antioxidant activity test}

The results of antioxidant activity showed that all ethyl acetate extracts of the endophytic fungi from turmeric flowers have antioxidant activity (Figure 2). Antioxidant activity is directly proportional to the concentration tested. The higher the concentration, the higher the antioxidant activity. The determination of antioxidant activity using the DPPH free radical scavenger method is a commonly used method. The principle of this method is the ability of test materials to donate hydrogen to DPPH free radical molecules (Babu et al., 2013). Therefore, free radicals will become more stable. The ability of the extract of endophytic fungi from turmeric flowers is closely related to the ability of the host plant as a producer of antioxidant compounds. This is because endophytic fungi will produce compounds and biological activity similar to their host plant (Zhao et al., 2010, p. 573). This is reinforced by previous studies that reported that turmeric flower extract showed high antioxidant activity. N-hexane extract of turmeric flower has high antioxidant activity with an $\mathrm{IC}_{50}$ value of $3.3 \mu \mathrm{g} / \mathrm{ml}$ (Kumar et al., 2016). In addition, fresh turmeric flower water extract has inhibitory activity against DPPH free radical by 23.08\% (Azmi et al., 2016).

The extract of single and mixed cultures showed antioxidant activity with $\mathrm{IC}_{50}$ values ranging between $247.90-634.64 \mu \mathrm{g} / \mathrm{ml}$ (Table 2). The activity of some endophytic fungi from the other tissues of the turmeric plant has also been previously reported. Ethyl acetate extract of endophytic fungi of
Bo.Ci.Cl.R5 isolated from turmeric rhizome tissue had an antioxidant activity with $\mathrm{IC}_{50}$ values of 91.70 $\mu \mathrm{g} / \mathrm{ml}$ (Septiana et al., 2019a). Likewise, ethyl acetate extract of endophytic fungi of Bo.Ci.Cl.A3 and Bo.Ci.Cl.D1 isolated from the root and leaf tissue of turmeric plant had an antioxidant activity with $\mathrm{IC}_{50}$ values of 75.71 and $24.04 \mu \mathrm{g} / \mathrm{ml}$ respectively (Septiana \& Simanjuntak, 2017; Septiana et al., 2019b). Widowati et al. (2016) also reported that endophytic fungi of K.Cl.Sb.B1 isolated from turmeric stem had antioxidant activity by inhibiting $78.81 \%$ DPPH free radicals. So, this study complements the data on endophytic fungi in each part of turmeric which has antioxidant activity.

Results of this study showed that each group (single culture, mixed culture, and positive control) had different antioxidant activities. The difference in $\mathrm{IC}_{50}$ values of both single and mixed cultures extracts can be caused by the differences in the types and amounts of antioxidant compounds contained (Huliselan et al., 2015). It is known that the primary secondary metabolite compound which has antioxidant activity in turmeric is curcumin. This compound is spread in almost all parts of plant tissue. Kumar et al. (2016) reported that curcumin was also detected to be contained in the turmeric flower tissue.

The $\mathrm{IC}_{50}$ value of antioxidant activity showed that the combination of isolates could increase the antioxidant activity. It can be seen that the mixed culture extract has a lower $\mathrm{IC}_{50}$ value compared to the single culture extract. In addition, the mixed culture showed a synergistic effect between endophytic fungal isolates in producing antioxidant compounds (Table 3). This is in line with the research of Jain et al. (2011) that reported that the synergistic effect would increase antioxidant activity and thus make it possible to use lower doses of each extract and prevent the side effects of using extracts in large quantities. Plant extracts have many antioxidant constituents in them. Their activity can increase because of the interaction of two or more compounds in combination (Wei \& Shibamoto, 2007). 


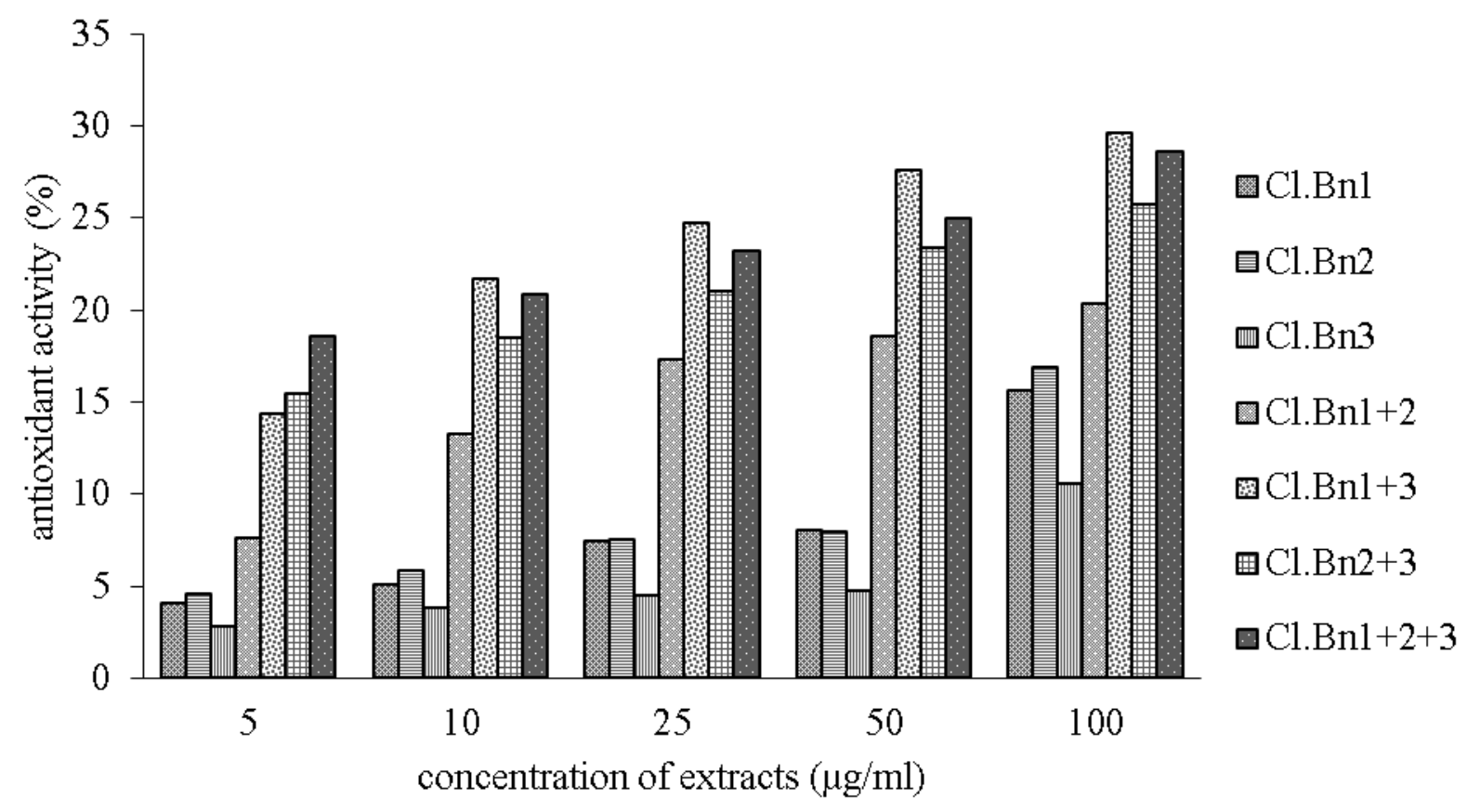

Figure 2. Antioxidant activity of extract obtained from single and mixed culture of endophytic fungi isolated from turmeric flowers

Table 2. $\mathrm{IC}_{50}$ values of extracts of endophytic fungi (single and mixed culture) isolated from the turmeric flowers

\begin{tabular}{|c|c|c|c|c|c|c|c|c|}
\hline & \multicolumn{8}{|c|}{ Extracts/tested compounds } \\
\hline & Cl.Bn1 & Cl.Bn2 & Cl.Bn3 & Cl.Bn1+2 & Cl.Bn1+3 & Cl.Bn2+3 & Cl.Bn1+2+3 & Vit. C \\
\hline $\mathrm{IC}_{50}(\mu \mathrm{g} / \mathrm{ml})$ & 404.61 & 380.80 & 634.64 & 366.32 & 247.90 & 345.50 & 319.74 & 3.56 \\
\hline
\end{tabular}

Table 3. Effect of mixed culture between endophytic fungal isolates on their antioxidant activity

\begin{tabular}{llll}
\hline Extracts & \multicolumn{4}{l}{ Antioxidant activity $\left(\mathrm{IC}_{50}\right.$ in $\left.\mu \mathrm{g} / \mathrm{ml}\right)$} \\
\cline { 2 - 4 } & Theoretical values* & Experimental values & Effect \\
\hline Cl.Bn1+2 & 392.71 & 366.32 & Synergies \\
Cl.Bn1+3 & 519.63 & 247.90 & Synergies \\
Cl.Bn2+3 & 507.72 & 345.50 & Synergies \\
Cl.Bn1+2+3 & 473.35 & 319.74 & Synergies \\
\hline
\end{tabular}

* Theoretical values were calculated as weighted mean $\mathrm{IC}_{50}$ values (considering additive contributions of individual species in each percentage). Additive effect: theoretical and experimental values reveal differences of lower than 5\%, Synergistic effect: experimental values are more than 5\% lower for $\mathrm{IC}_{50}$ when compared with theoretical values, Negative synergistic (antagonistic) effect: experimental values are more than 5\% higher for $\mathrm{IC}_{50}$ when compared with theoretical values (Queirós et al., 2009).

In general, the antioxidant activity of mixed culture of endophytic fungi is higher than the single culture. When several compounds with antioxidant properties are combined, different interactions can occur by showing various effects such as synergistic, antagonistic, or additive. (Nedamani et al. 2014). In the plant tissue, it is very impossible if only inhabited by one type of endophytic fungi. This can be proven through previous studies that always find more than one type of endophytic fungi from particular plant tissue. Therefore, in its natural condition, endophytic fungi will interact directly or indirectly with microbes or other endophytic fungi (Kusari et al., 2012).
Therefore, the antioxidant activity of the mixed culture of endophytic fungal extracts in this study is a manifestation of the process of synergistic interaction between endophytic fungal species in their natural environment.

Research on endophytic fungi from turmeric as a source of antioxidants and other active compounds that have biological activity has been carried out. In general, research on endophytic fungi from turmeric is still focused on the rhizomes. This is reasonable because the main active compound, curcumin, is abundant in the rhizome. In addition, the use of turmeric plants is also still limited to the rhizome and 
leaves. The research on turmeric flowers is still limited to the antioxidant activity and isolation of their essential oils (Kumar et al., 2016; Chane-Ming et al., 2002). The limited amount of research on turmeric flowers can be caused by the lack of utilization of turmeric flowers by society. The utilization of turmeric flowers is still limited as a food flavoring or eaten as a salad (Azmi et al., 2016). Research on endophytic fungi isolated from turmeric was also still focused on the rhizome. There are no studies that report the diversity and biological activity of endophytic fungi from turmeric flowers. Thus, this study is the first to report the endophytic fungi from turmeric flowers as a source of antioxidants. Data about the antioxidant activity of endophytic fungi from turmeric flowers can provide preliminary information for the utilization and development of antioxidants from endophytic fungi isolated from turmeric flowers. In addition, turmeric flowers extract is known to have antioxidant activity, so this study also confirms that endophytic fungi can produce compounds that have similar activity as its host plant. From the available scientific data, it is expected that the use of turmeric flowers is not limited for food, but can also be used as a source of antioxidant compounds and as traditional medicine.

\section{CONCLUSION}

The extract of single and mixed cultures of endophytic fungi isolated from turmeric flowers showed antioxidant activity. The combination of fungal cultures can increase the antioxidant activity of a single culture.

\section{REFERENCES}

Azmi, N. S., Bhat, R., \& Yeoh, T. K. (2016). Quality evaluation of novel cookies prepared by supplementing with fresh turmeric flower (Curcuma longa L.) extracts as a value-added functional ingredient. International Food Research Journal, 23(4), 1514-1522.

Babu, D., Gurumurthy, P., Borra, S. K., \& Cherian, K. M. (2013). Antioxidant and free radical scavenging activity of Triphala determined by using different in vitro models. Journal of Medicinal Plants Research, 7(39), 2898-2905.

Bustanussalam, Rachman, F., Septiana, E., Lekatompessy, S., Widowati, T., Sukiman, H., \& Simanjuntak, P. (2015). Screening for endophytic fungi from turmeric plant (Curcuma longa L.) of Sukabumi and Cibinong with potency as antioxidant compounds producer. Pakistan Journal of Biological Sciences, 18, 42-45.

Chane-Ming, J., Vera, R., Chalchat, J. C., Cabassu, P. (2002). Chemical composition of essential oils from rhizomes, leaves and flowers of Curcuma longa L. from Reunion Island. The Journal of Essential Oil Research, 14, 249-251.

Gulcin, I. (2012). Antioxidant activity of food constituents: an overview. Archives of Toxicology, 86, 345-391.

Huliselan, Y. M., Runtuwene, M. R. J., \& Wewengkang, D. S. (2015). Aktivitas antioksidan ekstrak etanol, etil asetat, dan $n$-heksan dari daun sesewanua (Clerodendron squamatum Vahl.). PHARMACON, 4(3), 155-163.

Jain, D. P., Pancholi, S. S., \& Patel, R. (2011). Synergistic antioxidant activity of green tea with some herbs. Journal of Advanced Pharmaceutical Technology \& Research, 2(3), 177-183.

Khani, M., Motamedi, P., Dehkhoda, M. R., Nikukheslat, S. D., \& Karimi, P. (2017). Effect of thyme extract supplementation on lipid peroxidation, antioxidant capacity, PGC- $1 \alpha$ content and endurance exercise performance in rats. Journal of the International Society of Sports Nutrition, 14, 1-8.

Kumala, S., \& Pratiwi, A. P. (2014). Efek antimikroba dari kapang endofit ranting tanaman biduri. Jurnal Farmasi Indonesia, 7(2), 111-120.

Kumar, A., Singh, M., Singh, P., Singh, S., Raj, P., \& Pandey, K. (2016). Antioxidant efficacy and curcumin content of turmeric (Curcuma longa L.) flower. International Journal of Current Pharmaceutical Review and Research, 8(3), 112114.

Kusari, S., Hertweck, C., \& Spiteller, M. (2012). Chemical ecology of endophytic fungi: origins of secondary metabolites. Chemistry \& biology, 19, 792-798.

Nedamani, R. E., Sadeghi, A., Ghorbani, M., \& Kashaninejad, M. (2014). Evaluation of antioxidant interactions in combined extracts of green tea (Camellia sinensis), rosemary (Rosmarinus officinalis) and oak fruit (Quercus branti). Journal of Food Science and Technology, 52(7), 4565-4571.

Nicoletti, R., \& Fiorentino, A. (2015). Plant bioactive metabolites and drugs produced by endophytic fungi of spermatophyta. Agriculture, 5(4), 918970.

Priska, M., Peni, N., \& Carvallo, L. (2019). Phytochemicals screening and antioxidant effectiveness of garlic (Allium sativum) from Timor Island. Biosaintifika, 11(1), 1-7.

Queirós, B., Barreira, J. C., Sarmento, A. C., \& Ferreira, I. C. (2009). In search of synergistic effects in antioxidant capacity of combined edible mushrooms. International journal of food sciences and nutrition, 60(S6), 160-172. 
Salini, G., Madhusoodhanan, A., Joseph, A., Mohan, A., Navya, R. K., \& Nair, V. V. (2015). Antibacterial and antioxidant potential of endophytic fungi isolated from mangroves. Der Pharmacia Lettre, 7(12), 53-57.

Septiana, E., \& Simanjuntak, P. (2017). Pengaruh kondisi kultur yang berbeda terhadap aktivitas antioksidan metabolit sekunder kapang endofit asal akar kunyit. Traditional Medicine Journal, 22(1), 31-36

Septiana, E., Bustanussalam, \& Simanjuntak, P. (2019a). Aktivitas penghambatan $\alpha$-glukosidase dan peredaman radikal bebas ekstrak kapang endofit yang diisolasi dari rimpang kunyit. Media Penelitian dan Pengembangan Kesehatan, 29, 189-196.

Septiana, E., Rahmawati, S. I., Izzati, F., \& Simanjuntak, P. (2019b). Antioxidant activity, total phenolic, and flavonoid contents of the extract of endophytic fungi derived from turmeric (Curcuma longa) leaves. Journal of Pharmaceutical Sciences and Community, 16, 7885.

Sitorus, M. S., Anggraini, D. R., \& Hidayat. (2017). Decreasing free radicals level on high risk person after vitamin $\mathrm{C}$ and $\mathrm{E}$ supplement treatment. IOP Conference Series: Materials Science and Engineering, 180(1), 1-8.
Tanvir, E. M., Hossen, M. S., Hossain, M. F., Afroz, R., Gan, S. H., Khalil, M. I., \& Karim, N. (2017). Antioxidant properties of popular turmeric (Curcuma longa) varieties from Bangladesh. Journal of Food Quality, 3, 1-8.

Tiwari, V., Shanker, R., Srivastava, J., \& Vanker, P. S. (2006). Change in antioxidant activity of spices-turmeric and ginger on heat treatment. Electronic Journal of Environmental, Agricultural and Food Chemistry, 5(2), 1313-1317.

Wei, A., \& Shibamoto, T. (2007). Antioxidant activities and volatile constituents of various essential oils. Journal of Agriculture and Food Chemistry, 55(5), 1737-1742.

Widowati, T., Bustanussalam, Sukiman, H., \& Simanjuntak, P. (2016). Isolasi dan identifikasi kapang endofit dari tanaman kunyit (Curcuma Longa L.) sebagai penghasil antioksidan. Biopropal Industri, 7(1), 9-16.

Zhao, J., Zhou, L., Wang, J., Shan, T., Lingyun, Z., Liu, X., \& Gao, L. (2010). Endophytic fungi for producing bioactive compounds originally from their host plants. In Mendez-Vilas A (Ed.), Current Research, Technology and Education Topics in Applied Microbiology and Microbial Biotechnology, Fist Edition (pp. 567-576). Badajoz:Formatex Research Center. 